Peer-Reviewed Article

ISSN: 2162-3104 Print/ ISSN: 2166-3750 Online

Volume 5, Issue 4 (2015), pp. 526-540

(C) Journal of International Students

http://jistudents.org/

\title{
Cognitive Skills Development Among International Students at Research Universities in the United States
}

\author{
Young K. Kim, $\mathrm{PhD}$ \\ Azusa Pacific University (USA) \\ David Edens, PhD \\ California State Polytechnic University, Pomona (USA) \\ Michael F. Iorio, $\mathrm{PhD}$ \\ Loma Linda University (USA) \\ Christie J. Curtis, PhD \\ Biola University (USA) \\ Edwin Romero, $\mathrm{PhD}$ \\ Mt. San Antonio College (USA)
}

\begin{abstract}
Set in the context of a statewide research university system, this study attempted to improve our understanding of cognitive skills development among international students. Specifically, this study examined how the patterns and predictors of cognitive skills development among this population differ from their domestic counterparts. The study utilized data from the 2010 University of California Undergraduate Experience Survey (UCUES). This study identified unique patterns in both cognitive skills development and college experiences among international students. Findings also suggest that some college experiences, such as research engagement with faculty and satisfaction with advising, can possibly facilitate greater gains in cognitive skills among international students. The study discusses the theoretical and practical implications of the findings.
\end{abstract}

Keywords: International students, Cognitive skills development, College experience

Colleges and universities in the United States are enrolling international students at an increasing rate. In the 2011-2012 academic year, there were 31\% more international students enrolled in U.S. higher education institutions than a decade ago (Open Doors, 2012). Despite the criticism that international students drain resources and capital from domestic student services and occupy seats that could be filled by domestic students, international higher education is valued in the United States for a number of reasons. First, international student recruitment has proven to be a lucrative source for admission dollars. International students contribute more than \$22.7 billion to the U.S. economy each year (Open Doors, 2012). Also, international students "contribute to the host nation's global competitiveness by swelling the numbers of highly trained September/October $2015 \quad$ http://jistudents.org $\quad$ Volume $5 \bullet$ Issue 4 
people in key disciplines" (Altbach, 2004, p. 20). Furthermore, international students add to the structural and cultural diversity of the campus population (Lee \& Rice, 2007) and provide an opportunity for increased cultural awareness and diverse experiences that enrich the campus experience for all students (Hechanova-Alampay, Beehr, Christiansen, \& Van Horn, 2002).

Considering these benefits associated with the presence of international students on campuses, college and university leaders acknowledge the importance of providing the necessary college experiences to meet the academic expectations of international students (Altbach, 1989; Cole \& Ahmadi, 2003; Grey, 2002; Lee \& Rice, 2007; Misra, Crist, \& Burant, 2003; Zhao, Kuh, $\&$ Carini, 2005). While there is an adequate body of research in higher education on international student population, they tend to mostly focus on either characteristics of successful international students or their retention/persistence (e.g., Bista \& Foster, 2011; Grey, 2002; Lee, 2010; Lee \& Rice, 2007, Mamiseishvili, 2010; Pedersen, 1991), relatively ignoring the examination of their actual "development" or "growth" during the college years and college experiences that contribute to such development or growth. In a methodological sense, most of the studies have also used data from a single institution. As an attempt to address these research gaps, this study examines patterns in and predictors of cognitive skills development among international students, utilizing a large, statewide college student dataset.

The purpose of this study is to improve the understanding of international students, by identifying background characteristics, precollege experiences, and college experiences that contribute to their cognitive skills development. Moreover, this study also examines how such factors as well as patterns in cognitive skills development among international students differ from their domestic counterparts. Set in the context of a statewide research university system, this study pursues the following three research questions: (1) Do international students differ in their cognitive skills development as well as in their background characteristics, precollege experiences, and college experiences from their domestic counterparts? (2) What student background characteristics, precollege experiences, and college experiences contribute to cognitive skills development among international students? (3) How do the predictors of cognitive skills development among international students differ from those among domestic students?

\section{Literature Review}

\section{Cognitive Skills Development in College}

Among other skills development (e.g., social, emotional, physical), cognitive skills development refers to "the acquisition of general intellectual or cognitive competencies and skills, which if they are not so directly tied to a particular curriculum or course of study, are nevertheless thought to be salient outcomes of postsecondary education" (Jones, 1994, as cited in Pascarella \& Terenzini, 2005, p. 155). Pascarella and Terenzini (2005) acknowledge that these cognitive skills receive many names: "critical thinking, reflective judgment, epistemological development, and so on" (p. 155). Moreover, cognitive skills development includes a variety of constructs and approaches such as intelligence, scientific problem-solving, metacognition, motivation to learn, and learning styles (King, 2009). While each of those terms differs slightly in concept and application, it seems clear that cognitive skills development is among important college student outcomes given its "applicability and utility across a wide range of different content areas" (Pascarella \& Terenzini, 2005, p. 155). 
While there are some mixed findings depending on the type of measures, researchers agree that college attendance generally facilitates students' cognitive skills development, including better critical thinking, more skillful pursuit of answers to difficult questions, and greater flexibility in understanding opinions other than their own (Doyle, Edison, \& Pascarella, 1998; Mines, King, Hood, \& Wood, 1990; Pascarella, Bohr, Nora, \& Terenzini, 1996; Rykiel, 1995). Studies also identified some specific college experiences that might contribute to gains or growth in students' cognitive skills: academic involvement/effort (Astin, 1993; Carini \& Kuh, 2003; Volkwein, Valle, Parmely, Blose, \& Zhou, 2000; Whitmire, 1998), peer interaction (Astin, 1993; Kitchener, Wood, \& Jensen, 2000; Twale \& Sanders, 1999; Whitt, Edison, Pascarella, Nora, \& Terenzini, 1999), student-faculty interaction (Ishiyama, 2002; Kim \& Sax, 2009, 2011; Kuh, 1995), service involvement (Astin \& Sax, 1998; Eyler \& Giles, 1999; Vogelgesang \& Astin, 2000), and diversity engagement (Kitchener, Wood, \& Jensen, 2000; Terenzini, Springer, Yaeger, Pascarella, \& Nora, 1996). These conclusions stand today and can be reasonably associated with international students as well.

\section{Cognitive Skills Development Among International Students in the United States}

The existing literature generally supports cognitive skills growth in domestic students during their postsecondary years, and the implication is that cognitive skills growth occurs in international students as well. Even though very few studies specifically examined cognitive skills development among students whose home country is not the United States, some understanding of the differences in cognitive skills development between international students and their domestic counterparts may be derived from some studies on cognitive skills development among different racial/ethnic groups. Kugelmass and Ready (2011) identified disparities in the cognitive skills development among racial/ethnic groups prior to college entry and after their collegiate experience. Similarly, Arum and Roksa (2008) reported that the cognitive skills gap between African American and White students widens during the first two years of college. After controlling for socio-demographic variables, the African-White disparity in academic growth was $22 \%$ (as cited in Kuglemass \& Ready, 2011). Given the findings that significant differences exist in cognitive skills development depending on students' racial/ethnic or cultural background, it might be assumed that there are differences in cognitive skills development among international students and their domestic peers. Indeed, Kugelmass and Ready (2011) indicated that international students in the United States tend to report greater gains in cognitive skills compared to their domestic counterparts. While these previous studies examined the differences in cognitive or intellectual development across different racial groups within domestic college student population, Zhao, Kuh, and Carini (2005) found similar types of racial/ethnic differences within international student population.

On the other hand, international students seem to face some challenges that inhibit their cognitive skills development in colleges and universities in the United States. For example, AlSharideh and Goe (1998) identified the loneliness experienced by international students as a challenge. They argued that these students feel isolated from their family and friends in their home country, and the loneliness adversely affects their cognitive skills development during college years. Hechanova-Alampay, Beehr, Christiansen, and Van Horn (2002) added intense feelings of anxiety and confusion as additional obstacles for international students to overcome. Moreover, research suggests that international students find American customs unfamiliar and interaction with Americans challenging. Lee and Rice (2007) found that international students perceive a lack of desire in Americans to understand a culture other than their own and that many 
international students lose social privilege in their native countries when they arrive in U.S. college campuses. Lee (2010) also identified cultural and language differences as other challenges international students face during their college years in the U.S.

While international students are not alone in the challenges that they face during their postsecondary years, the challenges or problems tend to be more exaggerated for international students compared to domestic students given their unique situation (e.g, they are away from their home environment/culture). This unique situation often leads international students to utilize different coping strategies to overcome their challenges than their domestic counterparts. For example, domestic students participate in more campus activities and seek a psychological sense of belonging to improve their cognitive skills development and personal growth (Zhao, Kuh, \& Carini, 2005). In contrast, finding an affinity group is elusive for many international students, which discourages them from participating in campus activities or events. This lack of social connection may interfere with the degree of cognitive skills development among international students in college. Zhao et al. (2005) also found that academic achievement seems to become a coping mechanism for international students to manage the stress associated with their college experiences. In other words, they argue that international students tend to heavily focus on their academic efforts to compensate for other aspects of their college experiences with which they feel dissatisfied.

Studies have also documented some college experiences that meaningfully contribute to cognitive skills development and other college outcomes among international students. Grayson (2008) found that active involvement in class activities and having no problem in making friends positively influence intellectual development among international students in the United States. However, Grayson (2007) also found that international students tend to be less involved in class activities compared to their domestic peers and spend more time in the library or in studying than domestic students. Similarly, Mamiseishvili (2012) and Zhao, Kuh, and Carini (2005) indicated that international students in the United States are more likely to be engaged in educationally purposeful activities including student-faculty interactions than their domestic peers. Other studies also found that language proficiency and the level of resiliency are significantly related to international students' academic success and other college outcomes (Andrade, 2009; Mamiseishvili, 2012; Stoynoff, 1997).

\section{Conceptual Framework}

The conceptual framework used to guide this study is based on three theories: Astin's (1993) Input-Environment-Output model, Schlossberg, Waters, and Goodman's (1995) Transition Theory, and Love and Guthrie's (1999) theory on the cultural differences in cognitive development. Using Astin's (1993) Input-Environment-Output (IEO) model as a conceptual framework of the study, this study attempts to investigate the unique effect of college experiences on college students' cognitive skills development by minimizing the confounding effects of student inputs.

Also, the current study assumes that international students have a unique set of college experiences that impact their cognitive skills development. Particularly, it is hypothesized that international students are transitioning into a new country and a new culture, as well as their new college environment; the degree to which an individual can cope with transitions is dependent upon the resources available and the individual's utilization of those resources. In this study, Schlossberg, Waters, and Goodman's (1995) transition theory is used to explain the possible 
impact of transitions on international students' college experiences and outcomes. Furthermore, this study considers the role played by cultural differences on cognitive skills development among international students by utilizing Love and Guthrie's (1999) theory.

\section{Method}

\section{Data Source and Sample}

This study utilized the 2010 University of California Undergraduate Experience Survey (UCUES), a biannual statewide survey administered to all undergraduate students on 10 University of California (UC) campuses. This survey is administered by the Office of Student Research at the University of California Berkeley, and is managed by the University of California Office of the President.

Given that this study is interested in measuring actual "development" or "growth" in cognitive skills among international students after they were fully exposed to actual college experiences, the study sample was limited to junior and senior undergraduate students $(\mathrm{n}=$ 32,426). The final analytical sample included 3\% international students, $58 \%$ female students, and $54 \%$ first-generation students. The racial/ethnic composition of the sample was as follows: 34\% White, 39\% Asian-American, 14\% Latino, and 3\% African-American.

\section{Variables}

Overall, this study utilized 19 variables for data analysis, 11 of which were factor scales (see Appendix A for the description of factor scale structures). The dependent variable of the study was college students' cognitive skills in their junior or senior year. To measure the cognitive skills, a factor scale $(\alpha=.85)$ was developed using five survey items assessing students' self-rating on their abilities to: (1) think analytically and critically, (2) write clearly and effectively, (3) read and comprehend academic material, (4) speak clearly and effectively in English, and (5) understand a specific field of study major.

According to Astin's I-E-O model (1993), independent variables of this study were organized in temporal order as follows: (1) student background characteristics, (2) pre-college experiences, and (3) college experiences. Student background characteristics included student gender, first-generation status, social class, and English speaking status, while pre-college characteristics included pretest measure (students' cognitive skills when they started the college) and high school GPA. College experiences included a broad range of variables thought to be associated with students' cognitive skills development, such as research engagement with faculty, satisfaction with major, satisfaction with advising, course engagement, and extracurricular engagement.

\section{Analysis}

After screening and cleaning the data based on recommendations from Tabachnick and Fidell (2007), the statistical analyses were conducted utilizing IBM SPSS Statistics version 20.0. First, we conducted multiple sets of t-tests, cross-tabulations with Chi-square tests, and ANOVAs to examine the differences in cognitive skills development, background characteristics, precollege experiences, and college experiences between international and domestic college students. Then, a series of hierarchical multiple regression analyses were conducted to identify the predictors of college students' cognitive skills development and examine how the predictors differ across international and domestic students.

\begin{tabular}{lll}
\hline September/October 2015 & http://jistudents.org & Volume $5 \bullet$ Issue 4
\end{tabular}




\section{Results}

\section{Differences in Cognitive Skills Development}

The results showed that both domestic and international students exhibited statistically significant positive change (i.e., growth or development) in cognitive skills during their college years (see Table 1), while domestic students reported a relatively larger growth than their international peers.

Table 1

Changes in the Level of Cognitive Skills for Domestic and International Students (Means and Standard Deviations)

\begin{tabular}{|c|c|c|c|c|c|c|c|}
\hline \multirow{2}{*}{\multicolumn{2}{|c|}{ Cognitive Skills Measures }} & \multicolumn{2}{|c|}{ Pretest (Skills Started) } & \multicolumn{2}{|c|}{ Posttest (Skills Current) } & \multicolumn{2}{|c|}{$\begin{array}{l}\text { Mean Differences Between } \\
\text { Pre- and Posttest Scores }\end{array}$} \\
\hline & & $\begin{array}{l}\text { Domestic } \\
\text { Students }\end{array}$ & $\begin{array}{l}\text { Intemational } \\
\text { Students }\end{array}$ & $\begin{array}{l}\text { Domestic } \\
\text { Students }\end{array}$ & $\begin{array}{l}\text { Intemational } \\
\text { Students }\end{array}$ & $\begin{array}{l}\text { Domestic } \\
\text { Students }\end{array}$ & $\begin{array}{l}\text { Intemational } \\
\text { Students }\end{array}$ \\
\hline \multicolumn{2}{|c|}{ Cognitive Skills Factor Scale } & $4.08(.77)$ & $3.62(.84)$ & $4.81(.69)$ & $4.32(.80)$ & $.73(.08)$ & $.71(.04)$ \\
\hline \multicolumn{8}{|c|}{ Individual Items: } \\
\hline & Critical Thinking & $3.99(.96)$ & $3.57(.98)$ & $4.78(.83)$ & $4.34(.91)$ & $0.79(.87)$ & $0.78(.90)$ \\
\hline & Clear and Effective Writing & $3.89(1.05)$ & $3.34(1.05)$ & $4.60(.92)$ & $4.06(.96)$ & $0.71(.95)$ & $0.74(.91)$ \\
\hline & Reading Comprehension & $3.94(1.00)$ & $3.57(1.02)$ & $4.74(.87)$ & $4.32(.92)$ & $0.80(.91)$ & $0.77(.92)$ \\
\hline & Speaking Clearly and Effectively & $4.80(1.08)$ & $3.69(1.19)$ & $5.11(.92)$ & $4.33(1.06)$ & $0.31(.68)$ & $0.65(.83)$ \\
\hline & Understanding Major & $3.49(.98)$ & $3.46(1.02)$ & $4.82(.85)$ & $4.55(.92)$ & $1.34(1.08)$ & $1.11(1.05)$ \\
\hline \multirow[t]{2}{*}{ Notes: } & \multicolumn{7}{|c|}{$\begin{array}{l}\text { Independent samples } t \text {-tests on pretest skills were significant }(p<.001 \text { to } p<.05) \text { for all variables except for clear and } \\
\text { effective writing and understanding major. }\end{array}$} \\
\hline & \multicolumn{7}{|c|}{ Independent samples $t$-tests on posttest skills were significant $(p<.001$ to $p<.01)$ for all variables. } \\
\hline
\end{tabular}

When it comes to individual items of cognitive skills factor scale, domestic students and international students had similar mean scores for changes in critical thinking skills. In contrast, differences between the two groups were evident when evaluating changes in both the speaking and writing abilities. Results showed that international students' gains in cognitive skills development during college years were mostly related to development in language-related abilities. International students reported a substantially greater development in the ability to speak clearly and effectively than their domestic counterparts. Growth in clear and effective writing skills was also greater for international students than for domestic students. On the other hand, domestic students showed larger gains than international students in reading comprehension skills and ability to understand academic major.

\section{Differences in Background Characteristics, Pre-College Experiences, and College Experiences}

Table 2 presents the differences in student background characteristics, pre-college experiences, and college experiences between domestic and international students. In general, both populations reported their socioeconomic status as middle class. As expected, the international student population learned to speak English later in life, whereas the domestic students were mostly native English speakers. 
Table 2: Differences in Background Characteristics, Pre-College Experiences, and College Experiences between Domestic and International Students

\begin{tabular}{|c|c|c|c|c|}
\hline & Domestic & International & & \\
\hline & $\begin{array}{l}\mathrm{M}(\mathrm{SD}) / \\
\text { Proportion }\end{array}$ & $\begin{array}{l}\mathrm{M}(\mathrm{SD}) / \\
\text { Proportion }\end{array}$ & $\chi^{2}$ & $F$ \\
\hline Gender & & & $14.68 * * *$ & \\
\hline Female & $58.35 \%$ & $51.39 \%$ & & \\
\hline Male & $41.65 \%$ & $48.61 \%$ & & \\
\hline High School GPA & & & $9.77 * *$ & \\
\hline $1.01-2.00$ & $0.01 \%$ & $0.00 \%$ & & \\
\hline $2.01-3.00$ & $5.99 \%$ & $1.86 \%$ & & \\
\hline $3.01-4.00$ & $94.00 \%$ & $98.14 \%$ & & \\
\hline First Generation Status & & & $45.72 * * *$ & \\
\hline Not First Generation & $45.91 \%$ & $58.16 \%$ & & \\
\hline First Generation & $54.09 \%$ & $41.84 \%$ & & \\
\hline Social Class & & & $165.31 * * *$ & \\
\hline Low-income & $11.93 \%$ & $1.67 \%$ & & \\
\hline Working Class & $24.11 \%$ & $14.84 \%$ & & \\
\hline Middle Class & $39.52 \%$ & $48.72 \%$ & & \\
\hline Upper Middle & $23.21 \%$ & $31.15 \%$ & & \\
\hline Wealthy & $1.23 \%$ & $3.59 \%$ & & \\
\hline When Learned to Speak English & & & $2687.43 * * *$ & \\
\hline Native Speaker & $67.11 \%$ & $5.75 \%$ & & \\
\hline Before Age 10 & $27.64 \%$ & $46.41 \%$ & & \\
\hline After Age 10 & $5.25 \%$ & $47.84 \%$ & & \\
\hline $\begin{array}{l}\text { Research Engagement with Faculty } \\
\text { Scale }\end{array}$ & $0.32(.47)$ & $0.33(.47)$ & & 3.09 \\
\hline $\begin{array}{l}\text { Satisfaction with Quality of Instruction } \\
\text { and Major Courses }\end{array}$ & $5.05(1.76)$ & $4.60(1.83)$ & & $46.60 * * *$ \\
\hline Satisfaction with Advising & $4.70(1.80)$ & $4.06(1.73)$ & & $93.54 * * *$ \\
\hline Satisfaction with Library Support & $5.40(1.27)$ & $5.27(1.39)$ & & $6.84 * *$ \\
\hline Course Engagement Scale & $3.17(1.05)$ & $2.96(1.02)$ & & $29.63 * * *$ \\
\hline $\begin{array}{l}\text { Critical Reasoning and Assessment of } \\
\text { Reasoning }\end{array}$ & $4.90(1.98)$ & $4.44(2.00)$ & & $39.31 * * *$ \\
\hline Elevated Academic Effort & $4.93(1.88)$ & $5.02(1.87)$ & & 1.51 \\
\hline Extracurricular Engagement & $5.22(1.58)$ & $5.30(1.62)$ & & 1.99 \\
\hline Time Employed & $4.78(1.74)$ & $4.27(1.72)$ & & $68.78 * * *$ \\
\hline $\begin{array}{l}\text { Time Allocation: Study and Academic } \\
\text { Activities Outside of Class }\end{array}$ & $3.90(1.59)$ & $4.07(1.72)$ & & $11.28^{* *}$ \\
\hline
\end{tabular}

${ }^{*} \mathrm{p}<.05, * * \mathrm{p}<.01, * * * \mathrm{p}<.001$

One noticeable difference between the two populations was their level of satisfaction with college. International students were generally less satisfied with their college experience, as September/October 2015 http://jistudents.org Volume $5 \cdot$ Issue 4 
compared to domestic students. International students reported significantly lower levels of satisfaction with the quality of instruction and courses in the major, advising, and library support. The lower level of satisfaction is noteworthy because satisfaction is a significant predictor of cognitive skills development for international students, which will be discuss later in this paper.

Finally, an interesting pattern was observed in classroom engagement versus engagement with activities outside the classroom among international students. International students in this study were less engaged in the classroom environment, whereas they invested more time in academic activities and effort outside of class.

\section{Differences in the Predictors of Cognitive Skills Development}

Table 3 presents the results of multiple regression analyses on cognitive skills development.

Table 3: Results of Regression Analyses Predicting Cognitive Skills Development for International and Domestic Students

\begin{tabular}{|c|c|c|c|c|c|c|c|c|}
\hline \multirow[b]{2}{*}{ Variable } & \multicolumn{4}{|c|}{ International Students $(N=532)$} & \multicolumn{4}{|c|}{ Domestic Students $(N=22,512)$} \\
\hline & $B$ & $S E B$ & $\beta$ & $R_{a d j}^{2}$ & $B$ & $S E B$ & $\beta$ & $R_{a d j}^{2}$ \\
\hline Student Background & & & & $0.09 * * *$ & & & & $0.08 * * *$ \\
\hline Gender & -3.80 & 0.00 & 0.00 & & -2.57 & 0.00 & -0.01 & \\
\hline First-generation status & -0.09 & 0.04 & $-0.06^{*}$ & & 0.01 & 0.01 & 0.01 & \\
\hline Social class & 0.00 & 0.03 & 0.00 & & 0.01 & 0.00 & $0.02 * *$ & \\
\hline Age when learned to speak English & -0.03 & 0.02 & -0.04 & & -0.06 & 0.00 & $-0.08 * * *$ & \\
\hline Pre-college Experiences & & & & $0.44 * * *$ & & & & $0.36^{* * *}$ \\
\hline Pretest: Cognitive skills & 0.48 & 0.03 & $0.53 * * *$ & & 0.45 & 0.00 & $0.51 * * *$ & \\
\hline HS GPA & 0.01 & 0.01 & 0.03 & & 0.01 & 0.00 & $0.04 * * *$ & \\
\hline College Experiences & & & & $0.60 * * *$ & & & & $0.51 * * *$ \\
\hline $\begin{array}{l}\text { Research engagement with faculty } \\
\text { scale }\end{array}$ & 0.10 & 0.05 & $0.06^{*}$ & & 0.01 & 0.01 & 0.01 & \\
\hline $\begin{array}{l}\text { Satisfaction with quality of instruction } \\
\text { and courses in the major }\end{array}$ & 0.03 & 0.02 & $0.08^{*}$ & & 0.04 & 0.00 & $0.10^{* * *}$ & \\
\hline Satisfaction with advising & 0.10 & 0.01 & $0.21 * * *$ & & 0.05 & 0.00 & $0.12 * * *$ & \\
\hline Satisfaction with library Support & 0.02 & 0.02 & 0.04 & & 0.01 & 0.00 & $0.02 * * *$ & \\
\hline Course engagement scale & 0.09 & 0.02 & $0.12 * * *$ & & 0.12 & 0.00 & $0.19^{* * *}$ & \\
\hline $\begin{array}{l}\text { Critical reasoning and assessment of } \\
\text { reasoning }\end{array}$ & 0.04 & 0.01 & $0.09 * *$ & & 0.03 & 0.00 & $0.10 * * *$ & \\
\hline Elevated academic effort & 0.02 & 0.01 & 0.06 & & 0.03 & 0.00 & $0.07 * * *$ & \\
\hline Extracurricular engagement & -0.03 & 0.01 & $-0.06^{*}$ & & -0.02 & 0.00 & $-0.04 * * *$ & \\
\hline Time employed & 0.01 & 0.01 & 0.02 & & 0.01 & 0.00 & $0.04 * * *$ & \\
\hline $\begin{array}{l}\text { Time allocation: Study and other } \\
\text { academic activities outside of class }\end{array}$ & 0.01 & 0.01 & 0.03 & & 0.00 & 0.00 & 0.00 & \\
\hline
\end{tabular}


The regression model estimating the cognitive skills development among international students explained $60 \%$ of the variation in cognitive skills development $(F(16,531)=50.42, p<.001)$, while the regression model for domestic students explained $51 \%$ of the variation in cognitive skills development $(F(16,22,495)=1,457.36, p<.001)$.

Each block in the regression analyses was statistically significant for both populations. All but two of the variables (research engagement with faculty and time allocation to studies and academic activities outside of class) were significant predictors of cognitive skills development for domestic students. For international students, however, research engagement with faculty, satisfaction with the quality of instruction and courses in the major, satisfaction with advising, course engagement, critical reasoning and assessment of learning, and extracurricular engagement were significant predictors of cognitive skills development.

\section{Limitations}

While findings of this study contribute to the existing literature about cognitive skills development among international students, this study is limited in several aspects. First, this study utilized survey data from a public, highly selective research university system on the West Coast; hence, the findings from the present study may not be equivalently applicable to other types of institutions (e.g., private, non-doctoral/research universities). Also, given that international students were severely underrepresented $(3.0 \%$ of the full sample) in the data, the current study was unable to disaggregate these students by racial/ethnic subgroups. Thus, this study is limited in the ability to fully address the unique patterns of cognitive skills development by racial/ethnic subgroups within international students. Another limitation is that the use of a secondary dataset limited the selection of variables for the analysis. Finally, it is also important to acknowledge that due to the difference in the number of cases between international and domestic students, the statistical reliability of the findings tend to be more robust for domestic students than that of international students.

\section{Discussion and Implications}

Using a statewide college student dataset, this study attempted to improve the understanding of the patterns and predictors of cognitive skills development among international undergraduate students in the United States. This study not only demonstrates significant differences in the level of cognitive skills development between international and domestic undergraduate students in the United States but also reveals both similarities and distinctions in the predictors of cognitive skills development across the two groups. Taken together, the findings of the study provide some meaningful insights to higher education research and practice.

First, the findings suggest that cognitive skills development seems to occur through different mechanisms for international students in the United States, as compared to their domestic peers. The gains in cognitive skills among international students tend to be related to their language skills growth. The results showed that international students experienced significant growth in speaking as well as writing abilities over the college years, which in turn related to their overall cognitive skills development. In other words, the findings suggest that international students tend to experience greater development in their cognitive skills as they are becoming more immersed in their new language and cultural environment. Knowing that the 
mechanism for cognitive skills development differs for international students as compared to domestic students, a suggestion for institutions of higher education that enroll international students is to provide specific services to support the language skills development of these students. International students are learning both the skills and information they need for their major, as well as the language in which they are being taught. It seems clear from the findings that supporting language growth is directly related to overall cognitive growth for international students.

Another key finding is that international students are generally less satisfied with their college experience and less engaged in the classroom when compared to their domestic counterparts. This finding is particularly interesting when considering the other findings of this study that international students were more engaged in academic activities outside of the classroom. The corollary of this finding is that there may be a relationship between engagement (both inside and outside of classroom) and satisfaction that needs further research within the international student population. This finding is particularly true considering that researchers examining traditional student populations have noted a link between engagement and satisfaction (Edens, 2012; Schreiner \& Louis, 2006; Schreiner \& Louis, 2008).

Finally, it is interesting to find that international students seem to benefit less from educationally meaningful college experiences than their domestic counterparts do. For example, both satisfactions with instruction/advising and course engagement are significant and positive predictors of cognitive skills development among international students. However, this research suggests that international students are generally less satisfied with the college experience and are less engaged in the classroom than their domestic peers. As a result, it is important for administrators serving international student populations to acknowledge the positive link between these college experiences and cognitive skills development when developing the policies, systems, and practices to support the development of this population.

\section{Implications for Research and Practice}

First, this study supports existing theories regarding classroom engagement and the cognitive skills development of international students. Grayson (2008) found that engagement in the classroom is the strongest predictor of intellectual development for international students. Findings of the present study are consistent with Grayson's and other previous findings (Kuh, Kinzie, Schuh, \& Whitt, 2005), demonstrating the positive relationship between international students' classroom engagement and their cognitive skills development. However, this study took a step further by suggesting that this relationship seems to be true regardless of the culture of origin. In other words, students who more frequently ask insightful questions, incorporate learning from other courses, and contribute to class discussions tend to obtain greater gains in cognitive skills than those who do not or do so less frequently; this finding holds across groupsinternational and domestic college students.

This study is also informative when considering the effect of culture on students' cognitive skills development. Love and Guthrie (1999) theorized that cognitive development is impacted by culture and that the culture in which a student develops will affect the manner of knowledge acquirement. This current study found that international students' research engagement with faculty is positively associated with their cognitive skills development. However, this was not the case for domestic students. This difference may be attributed to the cultures of origin, thus confirming Love and Guthrie's theory. Further research is required to 
examine both why research engagement with faculty improves cognitive skills development for international students while it does not for domestic students and what aspects of cultures of the two groups explain this difference.

Furthermore, the findings on research engagement with faculty have several practical implications with regard to the role that faculty play in the cognitive skills development of international students. The findings suggest that faculty members should understand the educational benefits of their collaboration with international students and provide multiple channels through which international students can be involved in their research to facilitate cognitive skills development among this population. In addition, faculty who serve as academic advisors to international students should play an important role in their cognitive skills development. Lee and Rice (2007) found that international students need additional support with navigation of educational resources in comparison to domestic students. In this study, satisfaction with advising was the strongest positive predictor of cognitive skills development among international students. Thus, the extra support that international students receive from academic advising likely correlates with their cognitive skills development. Advisors working with international students should be granted additional time and resources to direct international students, which in turn will enhance their cognitive skills development.

It is also important to note that being a first-generation college student is a negative predictor of cognitive development for international students, but not for domestic students. This difference is likely due to the existence of established and effective support systems for domestic first-generation college students. International student support services should model the support efforts provided to domestic first-generation college students in order to assure their cognitive skills development, while being sensitive to the cultural and developmental differences of the international student.

Finally, the present study provides some insights into the recruitment of international students in the U.S. higher education institutions. To successfully recruit international students, institutions and their members should understand which college experiences lead to the success of international students. Institutions should also be able to demonstrate that appropriate support services exist to help international students meet their goals once they arrive. Academic achievement is the most important facet of the college experience for international students, based on the amount of time these students spend in academic activities in comparison to domestic students. Therefore, it is important to establish advising programs and faculty research partnerships for international students in order to best recruit and support these students in their development.

\section{Conclusion}

International students consider academic achievement as an important factor when choosing to study in the United States (Grey, 2002; Heggins \& Jackson, 2003; Lee \& Rice, 2007; Mamiseishvilli, 2010; Misra, Crist, \& Burant, 2003). More specifically, international students expect positive changes (i.e., growth or development) in their college outcomes (Arkoudis, 2009; Grey, 2002; Heggins \& Jackson, 2003; Mamiseishvili, 2010; Misra, et al) when studying abroad. Therefore, cognitive skills development is an aspect of international student development that warrants considerable attention (King, 2009). Considering there has been little research that examines the relationship between college experiences and educational outcomes for international students (Grey, 2002; Misra, et al., 2003), the findings from this study meaningfully 
contributes to this body of research. Findings from this study should assist college and university professionals in understanding international students on their campuses and strategizing interventions to facilitate learning and development of this population.

Moreover, much of the earlier research concerning international students has utilized a single-institution dataset (Al-Sharideh \& Goe, 1998; Arnone, 2004; Bista \& Foster, 2011; Hechanova-Alampay, Beehr, Christiansen, \& Van Horn, 2002; Heggins \& Jackson, 2003; Lee, 2010; Li \& Kaye, 1998). This study, however, utilized data collected at multiple institutions within a large, statewide university system. As a result, not only did the exploration of cognitive skills development add to the understanding of academic achievement among international students during the college years, but also these findings from multiple-institutions data provide additional knowledge in some areas that have already been explored at single institutions.

\section{REFERENCES}

Al-Sharideh, K. A., \& Goe, W. R. (1998). Ethnic communities within the university: An examination of factors influencing the personal adjustment of international students. Research in Higher Education, 39, 699-725.

Andrade, M. S. (2009). The effects of English language proficiency on adjustment to university life. International Multilingual Research Journal, 3(1), 16-34.

Arkoudis, S. (2006). Teaching international students: Strategies to enhance learning. Centre for the study of higher education, University of Melbourne.

Astin, A. W. (1993). What matters in college? Four critical years revisited. San Francisco, CA: Jossey-Bass.

Astin, A. W., \& Sax, L. J. (1998). How undergraduates are affected by service participation. Journal of College Student Development, 39, 251-263.

Altbach, P. G. (1989). The new internationalism: Foreign students and scholars. Studies in Higher Education, 14, 125-136.

Altbach, P. G. (2004, March/April). Can the United States remain the top destination for foreign students? Change, 36(2), 18-24.

Arnone, M. (2004). Security at home creates insecurity abroad. The Chronicle of Higher Education, 50(27), 21-A22.

Arum, R., \& Roska, J. (2008). Learning to reason and communicate in college: Initial report of findings from the longitudinal CLA study. New York, NY: Social Science Research Council.

Bista, K., \& Foster, C. (2011). Issues of international student retention in American higher Education. The International Journal of Research and Review, 7(2), 1-10.

Carini, R., \& Kuh, G. (2003). 2002 NSSE-RAND construct-validation study: Some insights into the role of student engagement to student learning. Bloomington, IN: Indiana University Center for Postsecondary Research.

Cole, D., \& Ahmadi, S. (2003). Perspectives and experiences of Muslim women who veil on college campuses. Journal of College Student Development, 44, 47-66.

Doyle, S., Edison, M., \& Pascarella, E. (1998). The "seven principles of good practice in undergraduate education" as process indicators of cognitive development in college: A longitudinal study. In annual meeting of the Association for the Study of Higher Education, Miami, FL. 
Edens, D. (2011). Predictors of culinary students' satisfaction with learning. Journal of Hospitality \& Tourism Education, 23(3), 5-15.

Eyler, J., \& Giles Jr., D. E. (1999). Where's the learning in service-learning. San Francisco, CA: Jossey-Bass.

Grayson, J.P. (2007). Sense of coherence and academic achievement of domestic and international students: A comparative analysis. Higher Education, 56, 473-492.

Grayson, J. P. (2008). The experiences and outcomes of domestic and international students at four Canadian universities. Higher Education Research \& Development, 27(3), 37-41.

Grey, M. (2002). Drawing with difference: Challenges faced by international students in an undergraduate business degree. Teaching in Higher Education, 7, 154-166.

Hechanova-Alampay, R., Beehr, T. A., Christiansen, N. D., \& Van Horn, R. K. (2002). Adjustment and strain among domestic and international student sojourners: A longitudinal study. School Psychology International, 23, 458-474.

Heggins, W. J., \& Jackson, J. F. L. (2003). Understanding the collegiate experience for Asian international students at a Midwestern research university. College Student Journal, 37, 379-391.

Ishiyama, J. (2002). Does early participation in undergraduate research benefit social science and humanities students?. College Student Journal, 36, 380-386.

Kim, Y. K., \& Sax, L. J. (2009). Student-faculty interaction in research universities: Differences by student gender, race, social class, and first-generation status. Research in Higher Education, 50, 437-459.

Kim, Y. K., \& Sax, L. J. (2011). Are the effects of student-faculty interaction dependent on academic major? An examination using multilevel modeling. Research in Higher Education, 52, 589-615.

King, P. M. (2009). Principles of development and developmental change underlying theories of cognitive and moral development. Journal of College Student Development, 50, 597 620.

Kitchener, K., Wood, P., \& Jensen, L. (2000). Promoting epistemic cognition and complex judgment in college students. In annual meeting of the American Psychological Association, Washington, DC

Kugelmass, H., \& Ready, D. D. (2011). Racial/ethnic disparities in collegiate cognitive gains: A multilevel analysis of institutional influences on learning and its equitable distribution. Research in Higher Education, 52, 323-348.

Kuh, G. D. (1995). The other curriculum: Out-of-class experiences associated with student learning and personal development. Journal of Higher Education, 66, 123-155.

Kuh, G. D., Kinzie, J., Schuh, J. H., \& Whitt E. J. (2005). Assessing conditions to enhance educational effectiveness: The inventory for student engagement and success. San Francisco, CA: Jossey-Bass.

Lee, J. L. (2010). International students' experiences and attitudes at a US host institution: Selfreports and future recommendations. Journal of Research in International Education, 9, 66-84.

Lee, J. L., \& Rice, C. (2007). Welcome to America? International student perceptions of discrimination. Higher Education 53, 381-409.

Li, R. Y., \& Kaye, M. (1998). Understanding overseas students' concerns and problems. Journal of Higher Education Policy and Management, 20(1), 41-50.

Love, P. G., \& Guthrie, V. L. (1999). Understanding and applying cognitive development theory.

September/October $2015 \quad$ http://jistudents.org $\quad$ Volume 5•Issue 4


New Directions for Student Services, Number 88. San Francisco, CA: Jossey-Bass.

Mamiseishvili, K. (2012). International student persistence in U.S. postsecondary institutions. Higher Education, 64, 1-17.

Mines, R. A., King, P. M., Hood, A. A., \& Wood, P. K. (1990). Stages of intellectual development and associated critical thinking skills in college students. Journal of College Student Development, 31, 538-547.

Misra, R., Crist, M., \& Burant, C. J. (2003). Relationship among life stress, social support, academic stressors, and reactions to stressors of international students in the United States. International Journal of Stress Management, 10, 137-157.

Open Doors Fast Facts (2012). Open Door Report. Retrieved from http://www.iie.org/opendoors

Otten, M. (2003). Intercultural learning and diversity in higher education. Journal of Studies in International Education, 7, 12-26.

Pascarella, E. T., Bohr, L., Nora, A., \& Terenzini, P. T. (1996). Is differential exposure to college linked to the development of critical thinking? Research in Higher Education, 37, 159174.

Pascarella, E. T., \& Terenzini, P. T. (2005). How college affects students: A third decade of research. San Francisco: Jossey-Bass.

Pedersen, P. B. (1991). Counseling international students. The Counseling Psychologist, 19, 10-58.

Rykiel, J. D. (1995). The community college experience: Is there an effect on critical thinking and moral reasoning? Dissertation Abstracts International, 56:3824A.

Schlossberg, N. K., Waters, E. B., \& Goodman, J. (1995). Counseling adults in transition: Linking practice with theory ( $2^{\text {nd }}$ ed.). New York, New York: Springer.

Schreiner, L. A., \& Louis, M. (2006). Measuring engaged learning in college students: Beyond the borders of the NSSE. Paper presented at the Association for the Study of Higher Education, Anaheim, CA.

Schreiner, L. A., \& Louis, M. (2008). The engaged learning index: Implications for faculty development. Paper presented at the annual meeting of the Association for the Study of Higher Education, Jacksonville, FL.

Stoynoff, S. (1997). Factors associated with international students' academic achievement. Journal of Instructional Psychology, 24(1), 56-68.

Tabachnick, B. G, \& Fidell, L. S. (2007). Using multivariate statistics ( $6^{\text {th }}$ ed). Boston, MA: Pearson.

Terenzini, P. T., Springer, L., Yaeger, P. M., Pascarella, E. T., \& Nora, A. (1996). Firstgeneration college students: Characteristics, experiences, and cognitive development. Research in Higher education, 37, 1-22.

Twale, D., \& Sanders, C. S. (1999). Impact of non-classroom experiences on critical thinking ability. Journal of Student Affairs Research and Practice, 36, 108-121.

Vogelgesang, L. J., \& Astin, A. W. (2000). Comparing the effects of community service and service-learning. Michigan Journal of Community Service Learning, 25-34.

Volkwein, J. F., Valle, S., Parmely, K., Gary, B., \& Zhou, Y. (2000). A multi-campus study of academic performance and cognitive growth among native freshman, two-year transfers, and four-year transfers. Paper presented at the Annual Forum of the Association for Institutional Research, Cincinnati, $\mathrm{OH}$.

Whitt, E., Edison, M., Pascarella, E., Nora, A., \& Terenzini, P. (1999). Interactions with peers and objective and self-reported cognitive outcomes across three years of college. Journal of College Student Development, 40, 61-78. 
Whitmire, E. (1998). Development of critical thinking skills: An analysis of academic library experiences and other measures. College \& Research Libraries, 59, 266-273.

Zhao, C., Kuh, G. D., \& Carini, R. M. (2005). A comparison of international student and American student engagement in effective educational practices. The Journal of Higher Education, 76, 209-231.

NOTE - The authors presented an earlier version of this paper at the annual meeting of the American Educational Researcher Association, Philadelphia, PA, in April 2014.

\section{AUTHORS}

YOUNG K. KIM, Ph.D., is an associate professor in the Department of Higher Education at Azusa Pacific University. She received her Ph.D. in Higher Education at the University of California, Los Angeles. Her research interests include college student development, conditional effects of college experience, and diversity and educational equity in higher education. Dr. Kim has published in prestigious peer reviewed journals in the field of higher education, including Research in Higher Education and The Review of Higher Education. Email: YKKim@apu.edu

DAVID EDENS, Ph.D., is a lecturer in the Human Nutrition and Food Science at Cal Poly Pomona. He received his Ph.D. in Higher Education at Azusa Pacific University. His research has focused on student success and learning among diverse student populations including international students, non-traditional students, and students attending for-profit colleges and universities. Dr. Edens has presented at conferences such as AERA and CSRDE, as well as published for Noel-Levitz and in the Journal of Hospitality \& Tourism Education. Email: Dredens@cpp.edu

MICHAEL F. IORIO is an assistant professor in the Department of Radiation Technology at Loma Linda University; he is a Ph.D. candidate in higher education at Azusa Pacific University. His research interests include college student and faculty development, diversity and equity in higher education, and educational patterns among first-generation college students. Email: Miorio@llu.edu

CHRISTIE J. CURTIS, Ph.D., is Graduate Chair and TPA Mentor of the School of Education at Biola University. She received her Ph.D. in Higher Education at Azusa Pacific University. Her research interests include the challenges and benefits associated with international students, the importance of writing proficiency among domestic and international students, and the spirituality characteristics of educators teaching in other countries. Dr. Curtis has authored five levels of Grammar and Writing (Houghton-Mifflin) that has resulted in sales in excess of 1.5 million dollars. Email: Christie.j.curtis@biola.edu

EDWIN ROMERO coordinates student activities at Mt. San Antonio College. He is a doctoral candidate at Azusa Pacific University in the Ph.D. in Higher Education program. His research interests include student-faculty interaction, pathways to success for community college students, psychological engagement, and educational equity in higher education. Edwin has published in peer reviewed journals in the field of higher education, most recently in the Journal of Applied Research in the Community College. Email: Eromero44@mtsac.edu

September/October 2015 http://jistudents.org $\quad$ Volume 5 •Issue 4

